Rev. Int. Contam. Ambie. 37, 227-235, 2021

https://doi.org/10.20937/RICA.53837

\title{
CHARACTERIZATION OF A Microbacterium sp. STRAIN ISOLATED FROM SOILS CONTAMINATED WITH HYDROCARBONS IN THE BURGOS BASIN, MEXICO
}

\author{
Caracterización de una cepa de Microbacterium sp. aislada en suelos contaminados \\ con hidrocarburos de la cuenca de Burgos, México
María Antonia CRUZ-HERNÁNDEZ, Jessica REYES-PERALTA, Alberto MENDOZA-HERRERA, Gildardo RIVERA and Virgilio BOCANEGRA-GARCÍA*

Centro de Biotecnología Genómica, Instituto Politécnico Nacional, Boulevard del Maestro s/n Esquina Elías Piña, Colonia Narciso Mendoza, CP 88730, Reynosa, Tamaulipas, Mexico.

*Author for correspondence: vbocanegg@hotmail.com

(Received: December 2019; accepted: August 2020)

Key words: M. petrolearium, polycyclic aromatic hydrocarbons, bioremediation.

\begin{abstract}
The development of novel bioremediation strategies has focused on the isolation and identification of microorganisms that can thrive in polluted environments to evaluate their potential as biotechnological tools in bioremediation techniques. In this work, a bacterium isolated from hydrocarbon-contaminated soils from the Burgos basin was identified and its hydrocarbon degradation potential was evaluated. Identification based on sequencing the $16 \mathrm{~S}$ rRNA gene identified one of the isolates (R3) as Microbacterium petrolearium. This strain was mainly antibiotic-sensitive with elevated carbohydrate assimilation differing from previously reported strains. Moderate surfactant production (I24 $=22.97 \%$ ) was observed, which was absent in a cell-free extract. M. petrolearium R3 showed increased growth that correlated with pollutant concentration. For light crude oil, at a higher contaminant percentage, the R3 strain showed increased growth; however, in the case of diesel, no growth was detected. The aforementioned data indicate that M. petrolearium strain R3, isolated from local sources, has potential use as a tool for hydrocarbon-contaminated soil bioremediation.
\end{abstract}

Palabras clave: M. petrolearium, hidrocarburos aromáticos policíclicos, biorremediación.

\section{RESUMEN}

El desarrollo de nuevas estrategias de biorremediación se ha enfocado al aislamiento e identificación de microorganismos que puedan desarrollarse en ambientes contaminados, para evaluar su potencial como herramientas biotecnológicas en técnicas de biorremediación. En el presente trabajo, una bacteria aislada de suelos contaminados con hidrocarburos en la cuenca de Burgos fue identificada y su potencial para degradar hidrocarburos fue evaluado. La identificación basada en la secuenciación del gene del RNAr 16S sobre el aislado R3 indicó a Microbacterium pretrolearium. Esta cepa fue sensible a antibióticos con una asimilación de carbohidratos que difiere de cepas reportadas previamente. Se observó una moderada producción de surfactante (I24 = $22.97 \%$ ), el cual no se detectó en los extractos libres de células. M. petrolearium R3 
mostró un crecimiento incrementado en correlación con la concentración del contaminante. Para petróleo crudo ligero, a mayor concentración la cepa R3 mostró mayor crecimiento; sin embargo, en el caso del diésel no se detectó crecimiento. Los datos anteriores indican que $M$. petrolearium R3, aislada a partir de fuentes locales, tiene potencial para su uso en biorremediación de suelos contaminados con hidrocarburos.

\section{INTRODUCTION}

In the development of oil-derived products, petrochemical contamination is a constant source of residues that represent a risk for the ecosystem and the exposed population (Reyes-Reyes et al. 2018). Although several techniques have been used to remedy this contamination, bioremediation is widely considered effective and environmentally friendly. This has increased interest in the study of microorganisms that grow in contaminated ecosystems to evaluate their biotechnological potential (Muthukamalam et al. 2017). Biosurfactant release is a metabolic strategy used by microorganisms in the adsorption of hydrocarbons and hydrophobic compounds in general (Johnsen et al. 2005, Chong and $\mathrm{Li}$ 2017). It facilitates hydrocarbon degradation (Hmidet et al. 2017, Nievas et al. 2008). Numerous bacteria, such as Pseudomonas sp. (Singh and Tiwary 2017), Microbacterium sp. (Muthukamalam et al. 2017), Burkholderia sp. (Liu et al. 2019), and Bacillus sp. (Hmidet et al. 2017) degrade xenobiotics; however, since many are potential human pathogens, they can represent a health risks, making their use complicated.

Contaminated environments represent an opportunity for detecting strains that are ideal for potential bioremediation. A strain of Microbacterium was isolated from a sample of water contaminated with oil from Dagan, China (Wang et al. 2014). This strain, based on its phenotypic and genotypic features, was reported as a new species called Microbacterium petrolearium LAM0410. It demonstrated an ability to degrade light crude oil in in vitro conditions (Wang et al. 2014). Species of the gender Microbacterium can be isolated from diverse environmental sources, among these, the rhizosphere (Wongbunmak et al. 2017) and soil contaminated with polycyclic aromatic hydrocarbons (Sheng et al. 2009).

Hydrocarbon contamination at the Burgos basin, located in northern Tamaulipas, Mexico, has become a relevant problem. As an alternative for the solution and recovery of contaminated environments, diverse techniques that involve microorganisms have been proposed. Therefore, the isolation of microorganisms with the ability to grow in contaminated soil was carried out as a possible alternative for reducing environmental damage. One of the microorganisms isolated was a Microbacterium strain that has been previously reported with a potential for hydrocarbon biodegradation (Wang et al. 2014). Since some strains may present physiological differences according to the environment they adapt to, the objective of this work was to characterize and test the biotechnological potential of this strain for hydrocarbon bioremediation.

\section{MATERIALS AND METHODS}

\section{Isolation}

Sampling was carried out at the Burgos basin in the state of Tamaulipas. The geographic coordinates of the sampling site were $26^{\circ} 0^{\prime} 51^{\prime \prime} \mathrm{N}$ and $98^{\circ} 29^{\prime}$ $45^{\prime} \mathrm{W}$. The collection method used was a zigzag tracing five different points, collecting $1 \mathrm{~kg}$ of soil from each sample point. The soil was then homogenized to obtain a single sample. One gram of sample was mixed by mechanical shaking in a vortex mixer with $10 \mathrm{~mL}$ of sterile saline solution $(0.85 \% \mathrm{NaCl})$ and left to rest for $10 \mathrm{~min}$.

Afterwards, serial dilutions of $10^{-1}$ to $10^{-5}$ of the supernatants were placed in peptone-yeast extract (PY) medium and incubated at $30{ }^{\circ} \mathrm{C}$ for $48 \mathrm{~h}$ until growth was observed. Colonies were selected by phenotype to isolate the different types that could grow and were placed individually in PY medium until pure strains were obtained; these were then conserved in glycerol at $-80^{\circ} \mathrm{C}$ (Dasgupta et al. 2013, Reyes-Reyes et al. 2018).

\section{Bacterial identification by RFLP-sequencing}

DNA was extracted with the Wizard Genomic DNA purification kit (Promega) according to the manufacturer's instructions. Amplification of the $16 \mathrm{~S}$ rRNA gene was performed in triplicate using the universal oligonucleotides, 27f (5'- GAG AGT TTG ATC CTG GCT CAG), and 1495r (5'- CTA CGG CTA CCT TGT TAC GA) (Grifoni et al. 1995). The PCR product was digested with AluI enzyme (buffer 
$1 \mathrm{X}$, BSA $1 \mathrm{X}$, AluI $0.5 \mathrm{U}, \mathrm{PCR}$ product $3 \mu \mathrm{L}$, for a total volume of $10 \mu \mathrm{L}$ ) (Grifoni et al. 1995). The products were run in $1 \%$ agarose gel, which allowed the observation of restriction patterns. The digestion patterns of the isolates were grouped according to the similarity of each. After the groups were formed, one representative of each was chosen for sequencing. This was performed with an Applied Biosystems model 3130 sequencer using the Sanger method. After obtaining the sequences, multiple alignments were performed in triplicate of the DNAr 16S gene with the Geneious program (v. 4.8.5). The sequences were compared with the reference sequences available in the National Center for Biotechnology Information (NCBI) database using BLAST.

\section{Sequence analysis}

To observe the phylogenetic relationship of the Microbacterium petrolearium strain R3 with Microbacterium petrolearium LAM0410 and nearby species, a phylogenetic tree was constructed using the sequences of the $16 \mathrm{~S}$ rDNA gene with the neighborjoining method with 1000 bootstrap replications. The evolutionary distances were calculated with the 3-parameter Tamura method. A phylogenetic analysis was carried out with the MEGA7 program. Sequences of different species of Microbacterium were used. These were Herbiconiux flava NBRC 16403T (AB583921) and Leucobacter aerolatus $\mathrm{Sj}$ 10T (FN597581) as external groups. Sequences were obtained from the NCBI database.

\section{Antibiotic resistance}

An antibiogram was performed using the agar disk diffusion method (CLSI 2018) with sensidiscs (Bayer and BB Sensi-Disc) for gram-positive bacteria. The antibiotics used were cephalothin, cefotaxime, cefepime, cefuroxime, dicloxacillin, tetracycline and cefoxitin $30 \mu \mathrm{g}$, erythromycin $15 \mu \mathrm{g}$, ampicillin and gentamicin $10 \mu \mathrm{g}$, levofloxacin $5 \mu \mathrm{g}$, trimethoprim-sulfamethoxazole 23.75/1.25 $\mu \mathrm{g}$, and penicillin $10 \mathrm{U}$.

Isolated colonies were selected from a PY culture plate incubated for $24 \mathrm{~h}$ at $30^{\circ} \mathrm{C}$. From this, a direct suspension prepared in saline solution was adjusted to $0.5 \mathrm{McF}$ arland and inoculated on the dry surface of the plate ensuring a uniform distribution of the inoculum. Individual discs were placed on the agar surface and incubated at $30^{\circ} \mathrm{C}$. After the recommended incubation time, the plates were examined and the inhibition halo diameters around each disc were measured according to Clinical and Laboratory Standards Institute guidelines (CLSI 2018).

\section{Biochemical profile analysis}

The strain was assessed using API 20 NE and API $50 \mathrm{CH}$ (bioMérieux, Marcy l'Etoile, France) to determine its biochemical profile and carbohydrate fermentation. This was done according to Wang et al. (2014) in the Microbacterium petrolearium strain LAM0410. The analysis was carried out according to the manufacturer's instructions reading the results after $24 \mathrm{~h}$ of incubation.

\section{Evaluation of biosurfactant production Hemolytic activity}

This evaluation was performed according to Carrillo et al. (1996). The strains were seeded on plates with a blood agar base (MCD LAB) $(40 \mathrm{~g} / \mathrm{L})$ with $50 \mathrm{~mL} / \mathrm{L}$ of sheep blood and incubated for $48 \mathrm{~h}$ at $30^{\circ} \mathrm{C}$ (SHEL-LAB model 1545 incubator). A strain of Staphylococcus aureus was used as a positive control and the evaluation was performed in triplicate.

\section{Synthesis of a rhamnolipid biosurfactant}

The rhamnolipid biosurfactant was detected using the technique reported by Siegmund and Wagner (1991). To perform the evaluation, a drop of culture grown for $22 \mathrm{~h}$ (stationary phase) was deposited on a Petri dish with S-W medium $(0.2 \mathrm{~g}$ cetyl trimethyl ammonium bromide [CTAB], $0.005 \mathrm{~g}$ methylene blue, 20 g glucose, $0.7 \mathrm{~g} \mathrm{KH}_{2} \mathrm{PO}_{4}, 0.9 \mathrm{~g} \mathrm{Na}_{2} \mathrm{HPO}_{4}$, $2 \mathrm{~g} \mathrm{NaNO}_{3}, 0.4 \mathrm{~g} \mathrm{MgSO}_{4} \cdot 7 \mathrm{H}_{2} \mathrm{O}, 0.1 \mathrm{~g} \mathrm{CaCl}_{2} \cdot \mathrm{H}_{2} \mathrm{O}$, $15 \mathrm{~g}$ agar and $2 \mathrm{~mL}$ of trace elements $\left[\mathrm{H}_{3} \mathrm{BO}_{3}\right.$ $0.26 \mathrm{~g} / \mathrm{L}, \mathrm{Na}_{2} \mathrm{MoO}_{4} 0.6 \mathrm{~g} / \mathrm{L}, \mathrm{CuSO}_{4} \cdot 5 \mathrm{H}_{2} \mathrm{O} 0.5 \mathrm{~g} / \mathrm{L}$, $\left.\mathrm{MnSO}_{4} 0.5 \mathrm{~g} / \mathrm{L}, \mathrm{ZnSO}_{4} \cdot 7 \mathrm{H}_{2} \mathrm{O} 0.7 \mathrm{~g} / \mathrm{L}\right]$ per liter of deionized water). The plates were incubated for $48 \mathrm{~h}$ at $30^{\circ} \mathrm{C}$ (SHEL-LAB model 1545 incubator) to observe the formation of a complex between $\mathrm{CTAB}$ and methylene blue, revealed by the presence of a dark blue halo around the drop of culture. In this evaluation, Sphingobium yanoikuyae S72 was used as a positive control; assays were performed in triplicate.

\section{Percentage of the emulsification index (E24)}

This was measured using the method described by Illori et al. (2005). To evaluate the emulsification index, Sphingobium yanoikuyae S72 was used as the positive control strain and $10 \%$ Tween 80 as the positive control for emulsion; the evaluation was performed in triplicate. The emulsifying activity was measured by adding $2 \mathrm{~mL}$ of crude oil to $2 \mathrm{~mL}$ of a cell-free extract and mixing them in a vortex at high velocity for $2 \mathrm{~min}$. This same procedure was performed using a medium with bacterial cells and a cell-free extract. The emulsion was measured at two times ( $1 \mathrm{~h}$ and $24 \mathrm{~h})$. In both cases, the emulsification 
index (E24) was obtained by measuring the height of the emulsification divided by the total height multiplied by 100 .

\section{Evaluation of light crude oil and diesel as a carbon source}

A colony of the strain was inoculated into tubes with $4 \mathrm{~mL}$ of PY medium for Microbacterium petrolearium R3. The tubes were incubated with shaking (SHEL-LAB model 1545 incubator) for $24 \mathrm{~h}$ to obtain a bacterial biomass with an optical density of 0.4 . Finally, $1 \mathrm{~mL}$ of the culture was transferred to Eppendorf tubes, centrifuged, and washed twice with $1 \mathrm{~mL}$ sterile saline. From this stock, $1.5 \times 10^{5} \mathrm{CFU}$ was inoculated into each of the flasks that contained 30 $\mathrm{mL}$ of Bushnell-Haas minimal salts medium $\left(\mathrm{MgSO}_{4}\right.$ $0.2 \mathrm{~g} / \mathrm{L}, \mathrm{CaCl}_{2} 0.02 \mathrm{~g} / \mathrm{L}, \mathrm{KH}_{2} \mathrm{PO}_{4} 1 \mathrm{~g} / \mathrm{L}, \mathrm{K}_{2} \mathrm{HPO}_{4}$ $\left.1 \mathrm{~g} / \mathrm{L}, \mathrm{NH}_{4} \mathrm{NO}_{3} 1 \mathrm{~g} / \mathrm{L}, \mathrm{FeCl}_{3} \cdot 05 \mathrm{~g} / \mathrm{L}\right)$ using two concentrations ( 1 and $5 \%$ ) of light crude oil and diesel as the sole carbon source. The flasks were incubated with shaking (SHEL-LAB model 1545 incubator) at $30^{\circ} \mathrm{C}$ for 30 days; during this period, OD was measured daily at $600 \mathrm{~nm}$. For this, Bushnell-Haas medium with the contaminant and without the inoculum was used as the negative control to consider possible abiotic loss (Dasgupta et al. 2013).

\section{RESULTS}

\section{Isolation}

After $48 \mathrm{~h}$ of incubation at $30^{\circ} \mathrm{C}$, colonies were selected according to morphology, color, texture, and size. These were spread onto Petri dishes with PY culture medium until pure isolates were obtained. A total of 17 pure isolates were obtained; their characteristics are listed in table $\mathbf{I}$.

TABLE I. COLONY MORPHOLOGY OF THE PURE ISOLATES OBTAINED.

\begin{tabular}{llllll}
\hline Strain & Color & $\begin{array}{l}\text { Colony } \\
\text { morphology }\end{array}$ & Strain & Color & Morphology \\
\hline R01 & Orange & Smooth & R11 & Beige & Rough \\
R02 & Yellow & Rough & R12 & Yellow & Smooth \\
R03 & Yellow & Rough & R13 & Beige & Rough \\
R04 & Beige & Smooth & R14 & Orange & Smooth \\
R05 & Beige & Smooth & R15 & Beige & Rough \\
R06 & Yellow & Smooth & R16 & Beige & Rough \\
R07 & Orange & Smooth & R17 & Beige & Smooth \\
R08 & Orange & Smooth & R18 & Yellow & Smooth \\
R09 & Beige & Rough & R19 & Beige & Smooth \\
R10 & Beige & Smooth & & & \\
\hline
\end{tabular}

\section{Bacteria identification}

Ten isolates were sequenced according to their different enzyme digestion patterns. Once acquired, alignment results performed with BLAST allowed the identification of bacteria, as shown in table II. The R3 strain was identified as Microbacterium petrolearium (Table II).

TABLE II. RESULTS OF THE MOLECULAR IDENTIFICATION OF THE ISOLATES OBTAINED.

\begin{tabular}{ccl}
\hline Isolate & $\begin{array}{c}\text { Percentage } \\
\text { of similarity }\end{array}$ & Identification \\
\hline RO1 & 93 & Rhodococcus ruber \\
RO2 & 97 & Micrococcus luteus \\
RO3 & 95 & Microbacterium petrolearium \\
RO4 & 94 & Microbacterium marinilacus \\
RO5 & 93 & Staphylococcus haemolycticus \\
RO6 & 98 & Bacillus subtilis \\
RO7 & 98 & Bacillus pumilus \\
R08 & 94 & Micrococus luteus \\
R09 & 96 & Bacillius methylotrophicus \\
R10 & 98 & Arthrobacter sp. \\
\hline
\end{tabular}

Of the isolates identified by sequencing, only the R3 strain (Microbacterium petrolearium) was selected for the next part of the study. This was because this new species of the genus Microbacterium, reported by Wang et al. (2014), was isolated from soil contaminated with hydrocarbons. Therefore, we considered that its characterization could provide information regarding its potential use in studies related to xenobiotic degradation.

\section{Sequence analysis}

The resulting phylogenetic tree showed a similarity of $100 \%$ with the Microbacterium petrolearium strain R3 and the M. petrolearium strain LAM0410; in other words, both strains belong to the same species. This association is followed by a similarity of $99 \%$ with Microbacterium sediminis YLB-01 as a close species, and it establishes itself as a group external to Herbiconiux flava and Leucobacter aerolatus (Fig. 1).

\section{Antibiotic resistance}

Microbacterium petrolearium $\mathrm{R} 3$ was resistant to dicloxacillin $30 \mu \mathrm{g}$, with intermediate resistance to cefuroxime $30 \mu \mathrm{g}$, and sensitive to ampicillin $10 \mu \mathrm{g}$, cephalothin $30 \mu \mathrm{g}$, cefotaxime $30 \mu \mathrm{g}$, cefepime $30 \mu \mathrm{g}$, cefuroxime $30 \mu \mathrm{g}$, erythromycin $15 \mu \mathrm{g}$, 


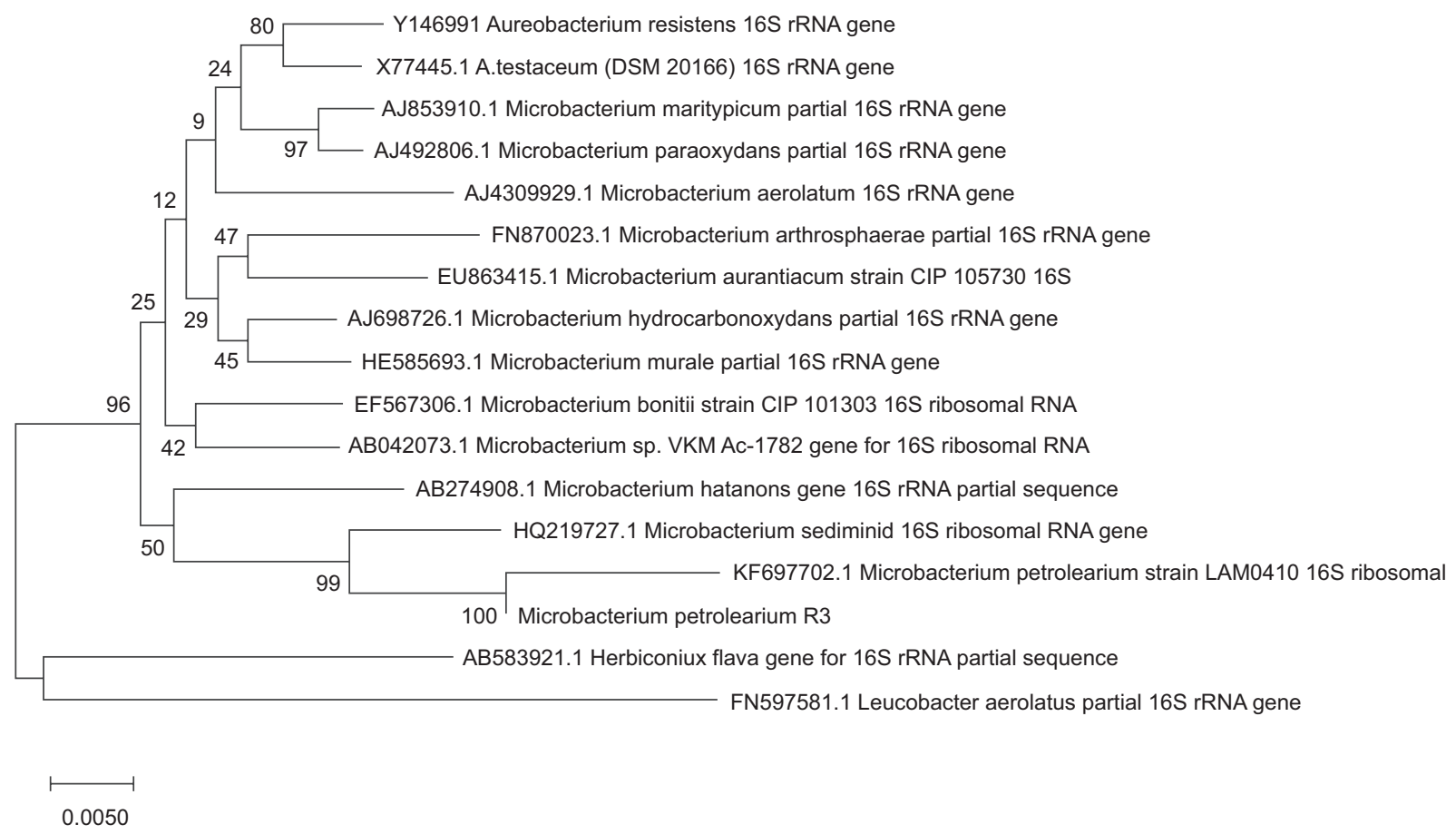

Fig. 1. Phylogenetic tree of Microbacterium petrolearium R3 made using the neighbor-joining method with a bootstrap of 1000 replications. The evolutionary distances were calculated with the 3-parameter Tamura method.

gentamicin $10 \mu \mathrm{g}$, levofloxacin $5 \mu \mathrm{g}$, penicillin $10 \mathrm{U}$, tetracycline $30 \mu \mathrm{g}$, trimethoprim-sulfamethoxazole 23.75/1.25 $\mu \mathrm{g}$, and cefoxitin $30 \mu \mathrm{g}$.

\section{Biochemical analysis (API)}

The results of API $20 \mathrm{NE}$ and API $50 \mathrm{CH}$ were analyzed after $24 \mathrm{~h}$ of incubation. The API $20 \mathrm{NE}$ evaluation showed that both strains (LAM0410 and R3) were negative for the reduction of nitrates, tryptophan, urea, arginine, and gelatin. Differences were observed in the assimilation of carbon sources, such as esculin and 4-nitrophenyl- $\beta$ D-galactopyranoside, with these being positive for $M$. petrolearium R3 and negative for $M$. petrolearium LAM0410, while LAM0410 was positive for D-maltose, and L-arabinose was negative for the R3 strain.

In the case of API $50 \mathrm{CH}$, the Microbacterium petrolearium strain $\mathrm{R} 3$ was able to use $\mathrm{D}$-fructose, inositol, amygdalin, esculin, D-cellobiose, D-sucrose, and 4-nitrophenyl- $\beta \mathrm{D}$-galactopyranoside as carbon sources. Differences in assimilation were found when comparing the strain LAM0410 since this strain is capable of assimilating D-sorbitol, D-trehalose, Larabinose, and D-maltose, which were negative for the R3 strain.

\section{Characterization of biosurfactant production Hemolytic activity and synthesis of a rhamnolipid biosurfactant}

In the evaluation of hemolytic activity and a rhamnolipid biosurfactant, the strains Staphylococcus aureus and Microbacterium petrolearium R3 grew in a blood-based medium; however, Microbacterium petrolearium R3 did not present hemolysis. In the analysis of rhamnolipid biosurfactant synthesis, the two strains showed growth; however, only Microbacterium petrolearium R3 was positive.

\section{Percentage of the emulsification index (E24)}

The percentage of the emulsification index after $1 \mathrm{~h}$ was $38.73 \%$ for Microbacterium petrolearium R3 and $26.1 \%$ for Sphingobium yanoikuyae S72 in the cell-free extract, and $36 \%$ for Microbacterium petrolearium $\mathrm{R} 3$ and $19.8 \%$ for Sphingobium yanoikuyae S72 in the cell culture. After $24 \mathrm{~h}$ of incubation, none of the strains presented emulsification in the cell-free extract; however, in the cell culture, the only strain that presented emulsification in $22.97 \%$ was Microbacterium petrolearium R3 (Table III). 
TABLE III. PERCENTAGE OF THE EMULSIFICATION INDEX (E24).

\begin{tabular}{lccccc}
\hline \multirow{2}{*}{ Strain } & \multicolumn{3}{c}{$\begin{array}{c}\text { Percentage of the emulsification index } \\
(\mathrm{E} 24)\end{array}$} \\
\cline { 2 - 3 } & \multicolumn{3}{c}{ Cell-free extract } & & \multicolumn{2}{c}{ Cell culture } \\
\cline { 2 - 3 } \cline { 5 - 6 } & 1 hour & 24 hours & & 1 hour & 24 hours \\
\hline M. petrolearium & 38.73 & 0 & & 36 & 22.97 \\
S. yanoikuyae S72 & 26.1 & 0 & & 19.8 & 0 \\
Tween 20 & 100 & 100 & & 100 & 100 \\
\hline
\end{tabular}

\section{Evaluation of light crude oil and diesel as a carbon source}

The assays of light crude oil and diesel as a carbon source for Microbacterium petrolearium strain $\mathrm{R} 3$ produced a growth curve of 30 days. In this, the Microbacterium petrolearium strain R3 was evaluated at concentrations of 1 and $5 \%$, respectively, for both contaminants, light crude oil (Fig. 2a) and diesel (Fig. 2b) for 30 days.

As seen in both graphs, Microbacterium petrolearium $\mathrm{R} 3$ shows minimum growth in the absence of either of the two contaminants. In the case of light crude oil, a slight increase in growth is seen at $1 \%$ after 15 days of incubation; however, when the $5 \%$ concentration is used, the growth increase is greater. When evaluating diesel using the concentrations of 1 and $5 \%$, growth is not observed in comparison to the growth seen with light crude oil. In contrast, growth inhibition is seen with the concentration used; that is, at a higher percentage of the contaminant, there is a greater growth inhibition of M. petrolearium R3.

\section{DISCUSSION}

The role of microbe activity in the biodegradation of hydrocarbons has been known for more than a century. The Mycobacterium strain isolated in this study is already adapted to hydrocarbon contaminated soils in the Burgos basin of Tamaulipas.

The analysis of the ribosomal gene 16S showed that the strain R3 belongs to the species Microbacterium petrolearium with an identity of $98 \%$ and a coverage of $99 \%$. This gene sequencing analysis indicated that the Microbacterium pretolearium reported by Wang et al. (2014) and our Microbacterium petrolearium strain isolated in this work belong to the genus Microbacterium and are closely related to Microbacterium sediminis MCCC 1A06153T, a thermotolerant, halotolerant
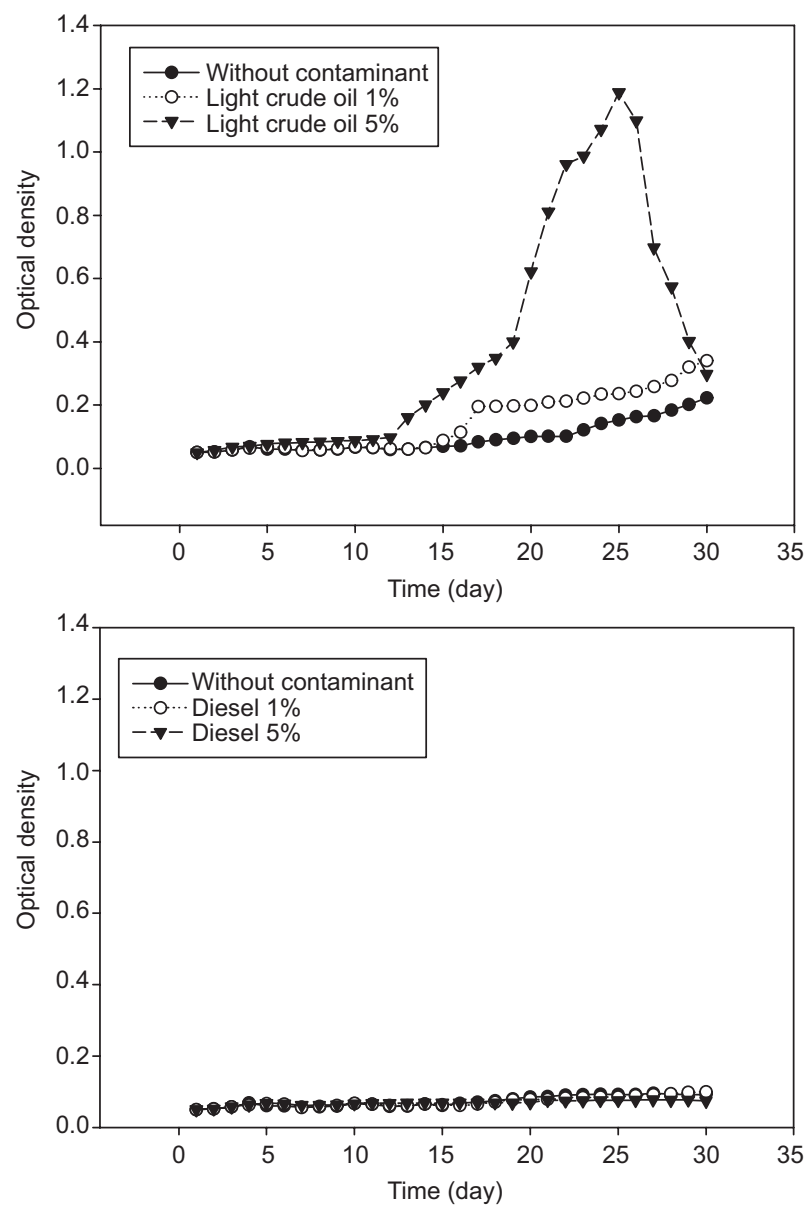

Fig. 2. Growth kinetics of Microbacterium petrolearium R3 at concentrations of 1 and $5 \%$ of light crude oil and diesel during a period of 30 days.

and alkali-tolerant strain isolated from deep-sea sediments (Yu et al. 2013). The species of the genus Microbacterium have been isolated from a large variety of ecosystems including sites contaminated with xenobiotics and evaluated according to these properties (Camacho-Chab et al. 2013). It is important to mention that it is a recently reported resistant strain; therefore, the fact that it was isolated from soil contaminated with hydrocarbon xenobiotics in this region is of great relevance due to its possible potential to degrade hydrocarbons and its adaption to these conditions, which arise as an alternative for reducing environmental damage.

Microbacterium petrolearium R3 presented resistance to dicloxacillin and intermediate resistance to cefuroxime. It has been reported that bacterial populations can survive in unfavorable environments in the presence of inhibitory substances such as antibiotics and hydrocarbons because of their ability to 
produce enzymes that inactivate or modify them and because they interrupt the function of the xenobiotic (Narváez-Flórez et al. 2008). Hydrocarbons are lipophilic compounds that in elevated concentrations inhibit microbe development, produce intoxication, induce a stress response in bacteria, and cell changes at the membrane, enzyme, and protein levels (Lee et al. 2018). The biochemical process of degradation of hydrocarbons by microorganisms involves the action of enzymes, including oxygenases, dehydrogenases, and hydroxylases that fragment aliphatic and aromatic hydrocarbons to transform and mineralize them (Muthukamalam et al. 2017). These organisms are capable of accumulating, transforming, or degrading contaminants to concentrations that do not produce harmful effects on health or the environment (Miranda-Martínez et al. 2007).

The results of the sources of carbon assimilation obtained from the R3 strain compared with those obtained by Wang et al. (2014) with the LAM0410 strain revealed differences because the latter is capable of assimilating D-sorbitol, D-trehalose, L-arabinose, and D-maltose, which were negative for the R3 strain. Wongbunmak et al. (2017) reported that Microbacterium esteraromaticum strain SBS1-7 is capable of assimilating L-arabinose. These variations occur because each strain is capable of assimilating carbon sources. The importance of evaluating their assimilation is directly related to the contribution of the nutrients necessary for the growth of the bacteria and that the carbon source used can influence the metabolites produced (Mouafo et al. 2018).

The release of biosurfactants is one of the strategies used by microorganisms to influence the absorption of hydrocarbons and hydrophobic compounds in general (Chong and Li 2017). These are characterized by their low toxicity and are biodegradable in comparison with those of synthetic origin making them an alternative for hydrocarbon remediation (Chong and Li 2017). Thus, they were indirectly characterized.

Initially, the evaluation was carried out measuring hemolytic activity, obtaining a negative result for $M$. petrolearium R3. The determination of hemolytic activity using blood agar is useful for the preliminary selection of bacteria that are potential producers of biosurfactants. Sarti and Miyazaki (2013) reported that Bacillus subtilis ATCC6633 released molecules with hemolytic capacity when using lamb blood-enriched agar-based medium, suggesting the production of substances with biosurfactant properties associated with hemolytic activity. However, other reports establish that the determination of hemolytic activity is not considered a definitive method. When evaluating a strain of Pseudomonas sp., Pacwa-Płociniczak et al. (2011) reported that the positive result of hemolytic activity of this strain was insufficient to confirm the production of biosurfactants because these also possess biotensioactives and $\beta$-hemolysins; therefore, the application of additional tests is required since not all biosurfactants have hemolytic activity. Also, compounds that are not biosurfactants can produce hemolysis.

Microbacterium petrolearium R3 had a positive result in the Siegmund and Wagner (SW) agar test. This test is commonly used for the detection of rhamnolipid biosurfactants; in some studies, it has been used as a semiquantitative test that relates the intensity of the halo with the amount of anionic tensoactive that interacts with $\mathrm{CTAB}$ and methylene blue (Becerra and Horna 2016). The SW technique arose as an alternative to the use of blood agar for the detection of biosurfactants since it has several advantages such as the non-catabolic repression of biosurfactant production, the non-occurrence of false positives due to the presence of hemolysins, and the greater stability of the agar (Tabuchi et al. 2015). The qualitative detection of rhamnolipid biosurfactant production in $M$. petrolearium R3 suggests that it possesses mechanisms that could facilitate the bioavailability of hydrocarbons.

In the evaluation of the emulsification index, two treatments were used, a cell-free extract and a cell medium. Twenty-four hours after emulsion, the cell medium presented an emulsification index of 22.97 $\%$, showing greater stability in the emulsion, while the cell-free extract did not conserve emulsion. The results varied depending on the microorganism studied and the carbon source. Illori et al. (2005) evaluated a strain of Aeromonas spp. isolated from tropical waters. The biosurfactants produced by the organisms emulsified a range of hydrocarbons obtaining an E24 of $65 \%$ when using diesel as a carbon source and of $22 \%$ when using hexane. In a study by Obayori et al. (2009), when evaluating the potential production of biosurfactants in Pseudomonas sp. P1, the E24 was $80.33 \pm 1.20$ using oil as a carbon source after eight days of incubation. The importance of the carbon sources used in this type of study makes it essential to evaluate the most adequate in assays for each microorganism.

There are different quantitative or qualitative methods available that vary in their precision and the objectives of production tests of potential 
biosurfactant-producing microorganisms. Among these, hemolytic activity assays and the CTAB agar method are considered primary assessments for biosurfactant-producing strains; however, more than one evaluation method should be included in the primary selection to identify possible biosurfactantproducing strains (Elazzazy et al. 2015).

Camacho-Chab et al. (2013) evaluated a non-toxic bioemulsifier synthesized by a strain of Microbacterium sp. MC3B-10. The bioemulsifier presented an E24 of $76 \%$ for crude oil, showing that some members of the genus Microbacterium produce biosurfactants as reported in this study.

The results in the evaluation of the tolerance of Microbacterium petrolearium R3 suggest that it could be assimilating light crude oil as its only source of carbon and energy. Muthukamalam et al. (2017) reported a study in which they isolated and characterized a strain identified as Microbacterium hydrocarbonoxydans BM. This strain was evaluated in in vitro assays using light crude oil as a carbon source and energy at concentrations of 1,2 , and $3 \%$. The results showed that this strain presented a greater growth in relation to an increase in the volume of hydrocarbon used, similar to the results obtained in the growth kinetics of the strain Microbacterium petrolearium R3 in the presence of crude oil. However, in this work, studies to evaluate the percentage of degradation were not performed; therefore, it is necessary to perform assays that involve the evaluation of percentages of degradation of contaminants by this species. In the case of the results obtained when diesel is added to the culture medium, these suggest that the use of Microbacterium petrolearium could be limited or null.

\section{CONCLUSIONS}

In this work, the characterization of a bacterium identified as Microbacterium petrolearium R3 by ribosomal gene $16 \mathrm{~S}$ sequencing is presented. This bacterium was sensitive to the tested antibiotics and differed in its ability to degrade hydrocarbons. We observed moderate production of a surfactant (I24 $=22.97 \%)$ that was not detected in the cell-free extract. It was also found that $M$. petrolearium $\mathrm{R} 3$ presented a notable increase in its growth in relation to the concentration of the added contaminant. In the case of light crude oil, a greater percentage of added R3 strain showed greater growth; however, for diesel, no growth was detected.

\section{REFERENCES}

Becerra-Gutiérrez L. and Horna-Acevedo M. (2016). Aislamiento de microorganismos productores de biosurfactantes y lipasas a partir de efluentes residuales de camales y suelos contaminados con hidrocarburos. Sci. Agropecu. 7 (1), 23-31. https://doi.org/10.17268/ sci.agropecu.2016.01.03

Camacho-Chab J., Guézennec J., Chan-Bacab M., RíosLeal E., Sinquin C., Muñiz-Salazar R., de la RosaGarcía S., Reyes-Estebanez M. and Ortega-Morales B. (2013). Emulsifying activity and stability of a nontoxic bioemulsifier synthesized by Microbacterium $\mathrm{sp}$. MC3B-10. Int. J. Mol. Sci. 14, 18959-18972. https:// doi.org/10.3390/ijms140918959

Carrillo P.G., Mardaraz C., Pitta-Alvarez S.J. and Giulietti A.M. (1996). Isolation and selection of biosurfactantproducing bacteria. World J. Microbiol. Biotechnol. 12, 82-84. https://doi.org/10.1007/BF00327807

Chong H. and Li Q. (2017). Microbial production of rhamnolipids: Opportunities, challenges and strategies. Microb. Cell Fact. 16, 137. https://doi.org/10.1186/ s12934-017-0753-2

CLSI (2018). Performance standards for antimicrobial susceptibility testing. 28th ed. CLSI supplement M100. Clinical and Laboratory Standards Institute, Wayne, Pennsylvania, USA.

Dasgupta D., Ghosh R. and Sengupta T.K. (2013). Biofilmmediated enhanced crude oil degradation by newly isolated Pseudomonas species. ISRN Biotechnol. 2013, 250749. https://doi.org/10.5402/2013/250749

Elazzazy A. M., Abdelmoneim T. S., and Almaghrabi O. A. (2015). Isolation and characterization of biosurfactant production under extreme environmental conditions by alkali-halo-thermophilic bacteria from Saudi Arabia. Saudi J. Biol. Sci. 22, 466-475. https:// doi.org/10.1016/j.sjbs.2014.11.018

Grifoni A., Bazzicalupo M., Di Serio C., Fancelli S. and Fani, R. (1995). Identification of Azospirillum strains by restriction fragment length polymorphism of the 16S ADNr and of the histidine operon. FEMS Microbiol. Lett. 127, 85-91. https://doi. org/10.1111/j.1574-6968.1995. tb07454.x

Hmidet N., Ayed H., Jacques P. and Nasri M. (2017). Enhancement of surfactin and fengycin production by Bacillus mojavensis A21: Application for diesel. Biodegradation 2017, 5893123. https://doi. org/10.1155/2017/5893123

Ilori M.O., Amobi C.J. and Odocha A.C. (2005). Factors affecting biosurfactant production by oil degrading Aeromonas sp., isolated from a tropical environment. Chemosphere 61, 985-992. https://doi.org/10.1016/j. chemosphere.2005.03.066 
Johnsen A.R., Wick L.Y. and Harms H. (2005). Principles of microbial PAH-degradation in soil. Environ. Pollut. 133 (1), 71-84. https://doi.org/10.1016/j.envpol.2004.04.015

Lee C., Chen I., Li C., and Chien C. (2018). Clinical benefit of ertapenem compared to flomoxef for the treatment of cefotaxime resistant Enterobacteriaceae bacteremia. Infect. Drug Resist. 11, 257-266. https:// doi.org/10.2147/IDR.S146923

Liu X., Hu X., Cao Y., Pang W., Huang J., Guo P. and Huang L. (2019). Biodegradation of phenanthrene and heavy metal removal by acid-tolerant Burkholderia fungorum FM-2. Front. Microbiol. 10, 408. https//doi: 10.3389/fmicb.2019.00408

Miranda-Martínez M.R., Delgadillo-Martinez J., Alarcón A. and Ferrera-Cerrato R. (2007). Degradación de fenantreno por microorganismos en la rizósfera del pasto alemán. Terra Latinoamericana 25(1), 25-33.

Mouafo T., Mbawala A. and Ndjouenkeu R. (2018). Effect of different carbon sources on biosurfactants production by three strains of Lactobacillus spp. Biomed Res. Int. 2018, 5034783. https://doi.org/10.1155/2018/5034783

Muthukamalam S., Sivagangavathi S., Dhrishya D. and Rani S. (2017). Characterization of dioxygenases and biosurfactants produced by crude oil degrading soil bacteria. Braz. J. Mirobiol. 48, 637-647. https://doi. org/10.1016/j.bjm.2017.02.007

Narváez-Flórez S., Gómez M.L. and Martínez M.M. (2008). Selección de bacterias con capacidad degradadora de hidrocarburos aisladas a partir de sedimentos del Caribe colombiano. Boletín de Investigaciones Marinas y Costeras 37 (1), 61-75. https://doi. org/10.25268/bimc.invemar.2008.37.1.182

Nievas M., Commendatore M., Estevas J. and Bucalá V. (2008). Biodegradation pattern of hydrocarbons from a fuel oil-type complex residue by an emulsifierproducing microbial consortium. J. Hazard Mater. 154, 96-104. https://doi.org/10.1016/j.jhazmat.2007.09.112

Obayori O.S., Ilori M.O., Adebusoye S.A., Oyetibo G.O., Omotayo A.E. and Amund O.O. (2009). Degradation of hydrocarbons and biosurfactant production by Pseudomonas sp. strain LP1. World J. Microbiol. Biotechnol. 25, 1615-1623. https://doi.org/10.1007/ s11274-009-0053-Z

Pacwa-Płociniczak M., Płaza G. A., Piotrowska-Seget Z., and Cameotra S.S. (2011). Environmental applications of biosurfactants: Recent advances. Int. J. Mol. Sci. 12, 633-654. https://doi.org/10.3390/ijms12010633
Reyes-Reyes M.A., Puentes-Cala E.A., Casanova-Montes E.L., López-Deluque F., Panqueva-Álvarez J.H., and Castillo-Villamizar G.A. (2018). Inmovilización de bacterias potencialmente degradadoras de petróleo crudo en matrices orgánicas naturales y sintéticas. Rev. Int. Contam. Ambie. 34 (4), 597-609. https://doi. org/10.20937/RICA.2018.34.04.04

Sarti C.G., and Miyazaki S.S. (2013). Bacillus subtilis crude extracts with antifungal activity against soybean (Glycine max) phytopathogens and Bradyrhizobium japonicum coinoculation effect. Agrociencia 47 (4), 373-383.

Sheng X. F., He L. Y., Zhou L., and Shen Y. Y. (2009). Characterization of Microbacterium sp. F10a and its role in polycyclic aromatic hydrocarbon removal in low-temperature soil. Can. J. Microbiol. 55 (5), 529535. https://doi.org/10.1139/W09-005

Siegmund I. and Wagner F. (1991). New method for detecting rhamnolipids excreted by Pseudomonas species during growth on mineral agar. Biotechnol. Tech. 5, 265-268. https://doi.org/10.1007/BF02438660

Singh P. and Tiwary B.N. (2017). Optimization of conditions for polycyclic aromatic hydrocarbons (PAHs) degradation by Pseudomonas stutzeri $\mathrm{P} 2$ isolated from Chirimiri coal mines. Biocatal. Agric. Biotechnol. 10, 20-29. https://doi.org/10.1016/j.bcab.2017.02.001

Tabuchi T., Martínez D., Hospinal M., Merino F. and Gutiérrez S. (2015). Optimization and modification of the method for detection of rhamnolipids. Rev. Peru. Biol. 22 (2), 247-258. https//doi.org/10.15381/ rpb.v22i2.11359

Wang H., Xiang T., Wang Y., Song J., Zhai Y., Chen X., Li Y J., Zhao B., Zhao B. and Ruan Z. (2014). Microbacterium petrolearium sp. nov., isolated from an oilcontaminated water simple. Int. J. Syst. Evol. Microbiol. 64, 4168-4172. https://doi.org/10.1099/ijs.0.061119-0

Wongbunmak A., Khiawjan S., Suphantharika M. and Pongtharangkul T. (2017). BTEX-and naphthalenedegrading bacterium Microbacterium esteraromaticum strain SBS1-7 isolated from estuarine sediment. J. Hazard. Mater. 339, 82-90. https://doi.org/10.1016/j. jhazmat.2017.06.016

Yu L., Lai Q., Yi Z., Zhang L., Huang Y., Gu L. and Tang X. (2013). Microbacterium sediminis sp. nov., a psychrotolerant, thermotolerant, halotolerant and alkalitolerant actinomycete isolated from deep-sea sediment. Int. J. Syst. Evol. Microbiol. 63 (1), 25-30. https://doi.org/10.1099/ijs.0.029652-0. 